\title{
OP ZOEK NAAR DE SPIN
}

\author{
DOOR \\ LOU LICHTVELD
}

Zooals Anansi de spin, zich in werkelijkheid altijd verbergt in post'oro, de beslagruimten en naden der houten negerwoningen, zoo verbergt hij zijn waren aard en zijn waarachtigen naam ook in de tallooze neger-vertellingen, waarvan hij de held is. Hij bedriegt niet alleen de personnages die met hem op avontuur gaan, maar ook den menschelijken onderzoeker, die hem gelukkig toch blijft achtervolgen, tot hij ergens komt waar Anansi zich bloot geeft en er kans is te weten te komen wie en wat hij is, waarom juist hij, een klein en nietig insect, dat geen bizonder opvallende eigenschappen bezit, tot held werd gepreconiseerd van vertellingen welke van de Senegal tot aan de Congo-rivier in omloop zijn, en die bij alle negers zoowel van het Zuid-Amerikaansche vasteland als van de West-Indische eilanden gekend en geliefd bleven.

Daar moet toch wel een gewichtige en nawijsbare reden bestaan, waarom de spin zulk een voorname persoonlijkheid werd in de dierfabels, en deze voornaamheid geenszins verloor toen de Afrikaansche negers in Amerika een nieuw doch hoe totaal verschillend vaderland vonden.

$\mathrm{Er}$ is reeds meermalen naar een verklaring gezocht, maar hoevelen zijn niet door Anansi bedrogen en om den tuin geleid; hoevelen heeft hij niet bij de neus gehad en ze listig een theorie in het oor gefluisterd, die toch op den duur niet steekhoudend bleek. Ik-zelf heb lang gemeend, en het zelfs geschreven, dat Anansi als totem-dier werd beschouwd, en de spin-vertellingen oorspronkelijk als totem-verhalen waren op te vatten. Maar hoe aanlokkelijk deze verklaring aanvankelijk ook schijnt, op den duur 
blijkt ze onhoudbaar. Immers toegegeven dat volgens een bekende wet de lofprijzingen op het totem-dier bij verdere ontwikkeling ook in pejorisatie en hekeldicht kunnen ontaarden, is het toch onaannemelijk dat de spin zijn rol van sluwaard en booze verleider zoo uitsluitend speelt ten koste van die van een beter creatuur, en dat er van de totem-functie niets nawijsbaars overbleef in de tori.

En hoe het voorkomen te verklaren van de spin-vertellingen bij die Afrikaansche volksstammen waar blijkens talrijke gegevens stellig andere dieren als totem in eere zijn? Waarom zouden dan juist die speciale totem-verhalen de andere zoozeer hebben verdrongen, dat tegenover de spinverhalen slechts één andere gelijkwaardige groep staat, namelijk die van het konijn in Afrika, dat bij de Noord Amerikaansche negers de beroemde Mr. Rabbit is geworden? Eerst bij de Zuidelijker Bantoenegers vindt men nog hert-vertellingen, welke overigens bij lange na niet de verbreiding en de rijkdom bezitten der Anansigeschiedenissen.

Maar er is een nog veel sterker argument. Geen enkel negervolk, geen stam nog zoo klein valt aan te wijzen, waar Anansi de eer geniet, of genoten heeft van een totem-dier. En begrijpelijk. Als totemdier komt het insect, voorzoover het niet als voedsel gebruikt kan worden, het laatst in aanmerking. Het groote en sterke en gevaarlijke dier, of het nuttige gezochte beest, of het eetbare, begeerde en nagejaagde dier wordt slechts stamvader en bondgenoot. Alleen zulk een dier wordt vereerd door clan-genootschap, door bondgenootschap, door voedsel-taboe en exogamie.

De eigenschappen van Anansi echter zijn alle juist in het tegengestelde te zoeken.

Bovendien komen wij met een totemistische theorie ook niet heel ver, en blijft nog altijd de oplossing noodig van de vraag, waarom of hij niet alleen in de fabels alle dieren de baas is, maar in de existentie der fabel zelve, spin's verhalen de eventueele totem-fabels van andere dieren hebben verdrongen of geabsorbeerd.

Lange en zorgvuldige onderzoekingen, speciaal op 
West-Afrika gericht, maar steeds met de toestanden van West-Indië tot achtergrond, hebben mij dan ook gedwongen van een totemistische verklaring der Anansi-verhalen af te zien. De residuën der totem-verhalen zijn hoofdzakelijk te vinden in de zegswijzen en odo, in de verzinnebeeldingen der volkswijsheid, deze fabels in een of twee volzinnen, soms enkel conclusies van onuitgesproken fabels, waaraan het idioom van welhaast alle neger- en alle creooltalen overrijk is. En het is merkwaardig te zien dat in die odo en zegswijzen andere dieren wèl een groote rol spelen, maar onder honderdtallen van voorbeelden de spin nauwelijks één enkele maal wordt genoemd. Het volgend overzicht van de rol welke dieren in de Surinaamsche odo spelen, moge dit illustreeren.

Van de mij bekende odo handelen over:

de vogel, kip (fốru) . . . . . . . 20

hond (dagu) . . . . . . . 19

rat (alàta) . . . . . . . 13

tijger (tigri) . . . . . . . . 10

paard (àsi) . . . . . . . . 10

koe (kau) . . . . . . . . . 10

geit (krabita) . . . . . . . . 10

stinkvogel (ting'-fōru) . . . . . . 9

krab (kràbu) . . . . . . . . . 8

schildpad (sėkrèpàtu) . . . . 8

slang (snètji) . . . . . . . 8

kat (puspusi) . . . . . . . . . 7

Andere dieren worden in een vijfhonderdtal odo niet, of slechts één enkele maal genoemd. Anansi vond ik slechts 3 maal, het konijn geen enkele keer.

Het blijkt duidelijk, dat odo-dieren juist die zijn, welke in aanmerking komen voor totem-dieren; en de drie odo waarin Anansi een rol speelt, zijn nog echte sententies uit gewone spin-geschiedenissen, of toespelingen daarop. Het zijn de volgende:

Anãsi tak': mi n'è du tu ogri. = De spin zegt: ik doe niet twee slechte dingen tegelijk.

Anãsi tak': ẽ no frédé, ma ẽ stjî è gro. = Despin zegt: hij is niet bang maar hij huivert. 
Dẽ tai anãsití jari: na a wãa dédi libi fu pur'ẽ na teté a sa go dédeे? = Men bond de spin tien jaren, zal hij nu sterven op de ééne dag die overblijft voor hij wordt losgemaakt?

Het is zonder meer toch bevreemdend dat van de tientallen spin-verhalen die Suriname kent, slechts dit beetje in de odo terecht is gekomen. De odo echter worden beschouwd als ernstige volkswijsheid, soms zelfs met een bezwerende, vervloekende kracht. Zij zijn overblijfselen van een ernstig en diep gefundeerd totemisme: zij zijn nagenoeg de laatste overblijfselen daarvan onder de negers van de nieuwe wereld.

De spin-vertellingen echter behooren in een geheel andere atmosfeer thuis. Ook zij hebben iets met bijgeloof, met het geheimzinnige van ,,jenseits" te maken; zij worden niet des daags, maar alleen na zonsondergang verhaald, en bij de oude, nog niet versteedschte negers slechts na het uittrekken van een ooghaar; maar ze gaan vergezeld van zang en scherts, ze zijn vol spot, en het is geen profanatie als daarbij hartelijk gelachen wordt.

Wanneer Anansi nu niets met de totem-dieren te maken heeft, blijft nog de mogelijkheid bestaan, dat zijn verhalen overblijfsels zijn van een zekere zoölatrie met andere dan totemistische bedoelingen. De spin aanbeden? Een zoo minuscuul en onbeteekenend dier zoo algemeen als godheid beschouwd dat daarvan een zoo uitgebreide fabel-verzameling over is? Het lijkt ongelooflijk en onwaarschijnlijk, en het zal wel hierom zijn dat in deze richting niet naar een verklaring van Anansi's fabelachtige existentie werd gezocht. In Afrika, waar diervereering wordt aangetroffen van de Senegal tot de Steenboks-keerkring, is geen spoor van eerbetoon aan de Spin de vinden. Het is ook zeker geen toeval dat Weissenborn's „Tierkult in Afrika" juist die dieren noemt, welke in Suriname talrijke odo bezitten, en van de Spin niets anders heeft te vertellen, dan dat een aardspin bij de Jaunde soms als orakeldier wordt gebruikt.

Toch meen ik in deze richting niet vruchteloos gezocht te hebben, geleid door talrijke aanwijzingen welke zich aanvankelijk verstrooid en onsamenhangend voordeden, 
maar die langzamerhand konden worden gegroepeerd tot een samenhangende, en naar ik meen aannemelijke en ten volle bewijsbare theorie.

Anansi's ware naam wil ik echter niet prijsgeven zonder een aantal noodzakelijke omschrijvingen, en zonder vooraf een uiteenzetting te hebben geleverd van het vreemdsoortige bestaan dat heer Spin in overouden tijd heeft gehad, van het werkelijk ,dubbele" leven dat hij leidde, en waarvan de vele fabels thans de min of meer misvormde legenden zijn geworden.

Er zijn enkele oude aanwijzingen, welke ons direct op het goede pad brengen, om de ware beteekenis van Anansi te achterhalen. In een der oudste beschrijvingen van de landen rond de golf van Guinea die wij bezitten, de „Nauwkeurige Beschrijving van de Guinese Goud-, Tanden Slavekust" door Willem Bosman, dateerende van vóór 1704 (het jaar van den eersten druk) wordt tweemaal over Anansi gesproken in een zonderling verband. De tweede maal heeft Bosman het over een spin van vervaarlijke grootte, die hij beschrijft als lang van lijf, met een spitse kop, tien ruige pooten zoo dik als een manspink.

„Deze Spin”, zegt hij daarop, „noemen de Negers $A n$ ansee. Sy gelooven dat de eerste menschen van den zelven gemaekt zyn; en niet tegenstaende eenige door ommegang met de Blanken anders geleerd hebbende, so zijn' er niet weinig, die by dat Geloof blyven, en welke waen haer niet uit 't hoofd is te praaten".

Hier heeft hij het dus over een reëel bestaand dier, waaromtrent het geloof heerscht waarop hij doelt wanneer hij voor de eerste maal over de spin spreekt en verklaart: ,- - het getal der geener, welke gelooven, dat de Mensch door den Anansié, zijnde een groote Spin, geschapen is, is noch heden ten dage niet weynig, werdende zulks van zommigen noch hardnekkig gedreeven".

Bosman kende juist die landen waar de Spin-vertellingen thans nog inheemsch zijn, en wij mogen op zijn gezag 
dus stellig aannemen, dat nog in het begin van de $18 \mathrm{e}$ eeuw aan Anansi door de bewoners van het noordelijk kustgebied van de golf van Guinea de beteekenis van een Schepper, dus van een godheid werd toegekend. Er bestaan echter geen bewijzen dat dit geloof door de negers in hun slavernij naar West-Indië werd medegenomen en behouden.

Wanneer Hartsinck in het tweede deel van zijn „Beschrijving van Guiana" (van 1770) over het bijgeloof der negerslaven spreekt, dan blijkt meermalen dat zijn wetenschap op die van Bosman teruggaat. Toch heeft wat hij over de Spin zegt, in dit verband wel aparte waarde: „De Negers zijn van nature allen Afgoden-dienaars; doch daar is geen Land of Dorp, ja bijna geen Geslacht onder hen, dat niet in Geloof en Godsdienst verschilt, schoon zij derzelve in onze Coloniën weinig of niet oefenen. Sommigen hunner verbeelden zich dat de Menschen door een groote Spin, dien zij Anansié noemen, zijn geschapen".

Maar de naam Anansié is blijkbaar overgenomen uit de corrupte eerste plaats van Bosman, die de naam in het tweede citaat wel juist schrijft: Anansee.

Wat is er in de dierfabels echter nog onmiddellijk over van het geloof in de Spin als schepper der menschen, en wellicht schepper van hemel en aarde? Welke legende getuigt nog van de goddelijke macht van Anansi?

In het 7e deel van „Atlantis”, waarin Leo Frobenius honderden hoogst merkwaardige neger-verhalen, direct uit de volksmond opgeteekend, heeft verzameld, vinden wij omtrent de Jukum (tusschen de Benue en de westgrens van Kamerun gevestigd) vermeld, dat in de sage waarmede voor hen de historie begint, de spin bij de schepping van den mensch de eigenaardige rol van wegwijzer heeft gespeeld.

Niemand bestond voor Afuma. Afuma was in de hemel. Hij kwam van de hemel omlaag op de aarde langs een spinnerag. Terwijl de spin (Tsafin) van de hemel naar de aarde daalde, wees hij de weg aan Afuma. Dan ging hij zelf weer terug naar de hemel, zonder Afuma de terugweg te wijzen. Deze ontmoette dan een vrouw, welke toen 
nog geen genitaliën bezat. Niettemin maakte hij haar zwanger aan de knie, en zoo ontstonden de eerste menschenkinderen. Niet direct door de spin, maar wel indirect, doordat hij den weg wees.

In dit verhaal is de spin dus een goddelijke wijze die meer dan de eerstbestaande weet, en die tevens een hemelbewoner is. Hij is dat in vele andere verhalen, en in een enkele vinden wij hem ook zelf nog als schepper van levende wezens, doch slechts heel terloops, zooals in een verhaal door Cronise en Ward in "Cunnie Rabbit, mr. Spider en the other beef" meegedeeld (ook vertaald door van Capelle in „Mythen en sagen uit West-Indië”), waar aan het eind van spin's overwinning op olifant en hippopotamus, deze de dieren in stukken hakt. De rest van de afval wierp hij in het water en toen kwamen er visschen te voorschijn. „Zoo is dus Spin eigenlijk de schepper der visschen geworden”, besluit de verteller zijn relaas, „en zoo heeft alles wat visch eet, veel aan hem te danken".

$\mathrm{Nu}$ wij echter eenmaal weten dat Anansi oudtijds in hoogere regionen zijn zetel had opgeslagen, is het eerst zaak na te gaan, hoe hij het daar heeft gesteld, daarna hoe hij er is gekomen, en vervolgens hoe of hij, nog geen twee eeuwen later, een zóó aardsch personnage is kunnen worden.

In Atlantis Band XII vinden wij een verhaal van de Kassaïden uit centraal-Congo, waarin Idu, de schildpad, door een list in de hemel weet te komen, en daar tegen Dihoka, de spin zegt: breng mij terug naar de aarde. Dihoka maakt een sterke weg en doet wat hem gezegd is. Idu komt nu terecht in „een land" waar niets dan water is. Als belooning geeft hij de spin het recht over alle wouddieren.

De verbindingsweg die de spin tusschen de hemel en het waterrijk maakt, vinden wij ook vermeld in een verhaal van de Mbundu uit Angola, door Meinhof in zijn „Afrikanische Märchen” geciteerd. Er hangt een spinnedraad van de hemel naar het waterrijk, en de zonnemeisjes dalen daarlangs af om water te halen. Wanneer de zonnedochter gaat huwen met een aardbewoner, krijgt de spin 
het verzoek een gansch net te weven, waarlangs de bruid kan worden neergelaten op aarde.

Merkwaardigerwijze is het motief van de spinnedraad tusschen hemel en aarde ook bij de Haussa, een Noordelijk, Soedaneesch beïnvloed volk bekend. (Schön: Magana Hausa, London 1885).

Niet altijd echter wordt er gesproken van een weg; soms wordt de spin zelf boodschapper, en in een zeer waardevol sprookje van de Tim uit Centraal Togo gaat de spin voor de vrouw van een opperhoofd niets minder dan de zon en de maan halen: hij heeft zich namelijk een kleed gemaakt van vogelveeren en kan vliegen. Het sprookje eindigt met de opmerking: Vroeger was er geen zon en geen maan. Spin heeft ze gehaald. (Atlantis Bd. XI).

Hier is Spin dus brenger van de gesternten, maar oorspronkelijk is hij de zon zelf. Hiervoor komt de taalwetenschap zelfs een aantal bewijzen voegen bij die welke de folklore weet aan te voeren.

Een zoo gezaghebbend Afrikanist als Meinhof maakt in zijn „Afrikanische Religionen” de opmerking, dat „Spin” en ,hemel" in het Duala niet alleen dezelfde naam hebben maar dat men daar het hemelgewelf opvat als het net van een reusachtige spin. Het woord dibobe beteekent in Kamerun, juist in het Yorubaland dat door Frobenius als de centrale zetel van de oude Atlantis-cosmogonie wordt beschouwd, evengoed Spin als hemel. Daar ook wordt de spin voor waarzeggerij, als „hemelsch” orakel gebruikt.

Zelfs in Oost-Afrika vertellen de Ziba van deze spin die ten hemel opstijgt en weer daalt. De zon aan de hemel zien zij als een geweldige spin die in haar stralen als in een net zit. (Meinhof: „Die Dichtung der Afrikaner”.).

Deze zoömorphe wereldvoorstelling is voor de WestAfrikanen een heel gewone. Waar niet de spin als zonnedier fungeert, is het de krab, zooals bij de Bakongo's, of de schildpad, waarvan Frobenius in Atlantis Bd. XII verschillende voorbeelden geeft uit de sprookjesschat der Kassaïden. Langs een draad gaat ook Ehoro, het konijn naar de hemel om bij zijn moeder te eten, terwijl hij dan telkens naar de aarde terugdaalt volgens de Yoruba (At- 
lantis Bd. X). Ahun, de schildpad, een dappere held, neemt echter deze rol van hem over, en met meer succes.

De Bakongo's hebben volgens Bittremieux (,,Mayombsche Volkskunst”) de volgende aanschouwing: „De Zon en de Maan zijn als twee reusachtige krabben die gestadig in oorlog liggen.... 't Schijnt dat de Zon maar twee pooten of beenen heeft, en nog zijn die slechts zichtbaar in 't droog jaargetijde". Ze gaat wel eens achter een wolk schuil om ongezien te kunnen eten.

Is het bij de Negers gewoonte om alle luchtverschijnselen als dieren voor te stellen, het is begrijpelijk dat de spin de krab en de schildpad én om hun morphologie, èn om hun langzaam-kruipende aard en hun schuilgaan in holen na gedurende korten tijd zichtbaar te zijn geweest, voor zonnedieren het meest in aanmerking kwamen. Ook hun bouw en oppervlakkige verschijning vertoont overeenkomst. Er zijn echter verschillende redenen waardoor de spin als zonnedier gemakkelijk over de andere kon domineeren.

Dat komt omdat van alle dieren juist de spin de eenige is die zich loopend langs een verticalen draad (zooals de neger de zonnebaan ziet) kan bewegen. En wiens existentie bovendien verbazing wekt omdat hij zelf deze draad voortbrengt.

Zelfs buiten het gebied der Spinvertellingen ontmoet men vaak de aanschouwing van zonnestralen als lange draden, die vanaf de centrale bal omlaagvallen. Dikwijls worden daaruit strikken gemaakt. (Frobenius: „Erlebte Erdteile" II, Wundt: Völkerpsychologie III). Nu eens laat de zonnegod een strik omlaag waaraan een haak is bevestigd om te visschen, dan weer heeft een achter de horizon verscholen God een slinger naar de zon geworpen om deze te vangen. Ook het zonnedier wordt op zulk een wijze bemeesterd.

Bij de Jukum werd de zon in de gedaante van een paard, de maan als schaapsbok gevangen. En Frobenius zegt na dit verhaal (Atlantis Bd. 7) „Hier wil ik een randglosse tusschenvoegen. Ik ken het motief zoowel van de Togostammen als van Kassaïden. Overal is de zon de 
gevangen dief; dus neem ik aan dat dit ook bij de Jukum de bedoeling is en dat deze schaapsbok ook de zon belichaamde. Dat schijnt mij ook uit het slot af te leiden".

Dit moeten wij vooral goed onthouden: de zon is de gevangen dief, zooals Anansi overal de dief is die men op de hielen zit. In West-Afrika is de zon ook altijd mannelijk, (in tegenstelling met het overige Afrika; zie Frobenius "Erlebte Erdteile” VI), zooals de spin een manspersoon is die nooit een vrouwelijke rol te spelen krijgt.

Wat de taalkundige identiteit tusschen ,spin” en „hemel” of „zon” betreft, zijn er nog merkwaardige bizonderheden aan te voeren.

In de meeste West-Sudan-talen gaat de naam voor „spin" terug op de stam - na - (volgens Westermann „Die Westliche Sudansprachen”).

Maar ook het woord „vuur" gaat in de meeste van deze talen terug op een stam - ná - , terwijl Westermann nog melding maakt van een stam $n a$ met de beteekenis „Oberseite, oben", welke ook in eenige van deze talen is te vinden.

Het taalkundig verband, of althans de groote gelijkenis tusschen de woorden voor „Spin”, „vuur” en ,ddaarboven" stemt wel heel goed overeen met het verband dat wij reeds zagen tusschen Anansi en „het groote vuur daarboven". Het zou niet de eerste maal zijn dat een oorspronkelijk visueele en ideologische gelijkenis en een latere associatie ook haar uitdrukking vonden in een phonetische overeenstemming.

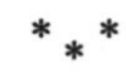

Het zou echter vreemd zijn, wanneer niets van het „zonnig" karakter van Anansi in de spin-verhalen was overgebleven. Maar heel veel andere onbegrijpelijke hebbelijkheden van onze held laten zich nu eerst verklaren, nu wij zijn ,"vurigen” en ,hemelschen” aard ontdekt hebben.

De spin als belichaming van de hemel zelf, vinden wij in een sprookje van de Bassari uit Noord-Togo, dat stof leent tot zeer vele beschouwingen. (Atlantis Bd. XI). 
Een opperhoofd stelt de vraag wie uit acht hakijzers iets behoorlijks weet te maken. Alleen de spin komt opdagen en zegt dat hij de zon en de maan daaruit weet te vervaardigen. In een vogelkleed vliegt de spin naar Unumbotte „God”, en vraagt deze of hij uit de hakijzers zon en maan wil maken. Dit gebeurt, en de spin krijgt ze mee. Maar als hij ze naar de aarde wil dragen, zijn ze hem te heet, en brandt hij z'n vingers, zoodat hij zijn weg slechts langzaam, bij kleine gedeelten aflegt.

Eindelijk kwam hij met zijn vracht op aarde, waar hij de maan in het water wierp. Daar koelde deze af. De zon wierp hij op de aarde; daar ging deze onder. Later wierp hij de zon weer naar boven, en sindsdien gaan de zon en de maan regelmatig op en onder.

Hoewel de spin hier nog geheel in zijn astraal milieu verkeert, wordt reeds een zwakke poging gedaan tot biologiseering van de fabel. Elementen zijn ingeschoven om de spin ook natuurkundig en zoölogisch te verklaren.

In het reeds genoemde verhaal van de Tim haalt de spin ook in zijn vogelkleed zon en maan, en elders oefent hij de functie van de zon zelf uit, als deze gehaald wordt.

Een verhaal uit centraal Soedan (Atlantis IX) brengt het gewone relaas van een weddenschap tusschen de spin, de olifant en het nijlpaard. $\mathrm{Na}$ allerlei verwikkelingen zegt de spin tot de olifant: nu, het is ook beter om geen ruzie met mij te maken, want als ik mijn arm naar je uitstrek, moeten al je ledematen verdorren. Sindsdien heeft niemand in het bosch de spin zijn voedsel bestreden.

Heeft de spin als zonnedier verdorrende kracht, hij weet ook als een goed zonnedier vruchtbaarheid te brengen en voedsel te verschaffen. In een sprookje van de Tim maakt de spin, wanneer er groote hongersnood op aarde heerscht, een draad naar de hemel, en haalt daarbij Elim, de wouw, telkens voedsel.

Wanneer dit hem op het laatst geweigerd wordt, doodt hij Elim en neemt hij al het eten mee naar de aarde. Sindsdien is er eten op de aarde: Spin heeft het eten op aarde gebracht (Atlantis Bd. XI).

In hoevele West-Indische Anansi-tori wordt nu ook 
niet van hongersnood verteld; en telkens is het ook daar de spin die - zij het als dief - voedsel als verzinnelijking van vruchtbaarheid verschaft. Ook in de West-Indische verhalen zijn de solare eigenschappen van de spin nog nawijsbaar. In Van Cappelle's „Mythen en sagen uit West-Indië "die ik gemakshalve als bron zal nemen, vinden wij een verhaal waarin Anansi een ijzeren huis heeft, waar hij zijn vrienden binnen lokt (no. 3). Rondom het huis wordt een vuur aangelegd, en de dieren verbranden daarbinnen.

Dit vurige huis van de Spin is wel iets zeer zonderlings, en wellicht het aannemelijkst wanneer wij het beschouwen als de gloeiende tropenwereld die door Anansi, het vurige hemellichaam wordt bestookt en verschroeid.

Spin vertoeft ook bij de Surinaamsche negers in oorden waar hij op voet van gelijkheid staat met de hemelverschijnselen. Er is een verhaal waarin hij ruzie heeft met de bliksem (no. 22). Eertijds waren zij goede vrienden, en bezochten zij elkander dikwijls; later wordt zelfs vermeld dat zij elkaar bezochten te middernacht, op een tijd dat Anansi, de zon, vrijaf heeft om zijn vrienden te frequenteeren. Doch als de ruzie er is, en Bliksem door Anan$s i$ 's list reeds verschillende dieren heeft gedood, dan moet de spin er eindelijk zelf aan gelooven, en wordt hij doodgeslagen. Ook in de West Afrikaansche sprookjesschat wordt de vriendschap van Anansi met de Donder (= bliksem) gevonden; in een verhaal uit Barker en Sinclair's „West African Folktales” ontvangt hij van „Thunder" een zichzelfvullende pot, en later een knuppel-uit-de -zak.

Zuiverder specimen van een zonnemythe is nauwelijks denkbaar; juist door de camouflage bleef de solare beteekenis van de spin zoo goed behouden. Dat deze het onderspit delft is het gevolg van een bijna wetmatig functioneerend omkeeringsprincipe in de mythologie (,Gesetz von der Umkehrung”. Zie Frobenius „Erlebte Erdteile” I). In het volksgeloof is de overwinnende kracht van de zon nog behouden gebleven; daar bijvoorbeeld waar de Surinaamsche neger gelooft dat de Azèma aan de rondgestrooide 
korrels rijst moet blijven doorpikken tot het dag wordt. Dan is hij onschadelijk, want ,zoodra het zonlicht op hem schijnt, valt hij dood neer". (v. Cappelle, pag. 253). Een Noord-Amerikaansche analogie wordt door Puckett in „Folkbeliefs of the Southern Negro” vermeld onder „Lockin' de bowels”. Als het bezweringsmiddel onder een boom begraven is, dan gelooft men dat de bezworene zwakker en zwakker wordt, ,elke keer als de zon ondergaat”. Van een vijand die sterft zegt men daar dat hij ,goes down wid de sun". In hun droomuitlegkunde beteekent de zon het ergste van alles: moeders dood. Allerlei andere gebruiken en aanschouwingen zijn nog aan te voeren, welke terug te brengen zijn tot de vroegere Afrikaansche zonne-vereering, waarover Ellis spreekt in zijn „Ewe-speaking peoples”, en Frobenius in zijn „Zeitalter des Sonnengottes".

En wanneer in de Zuidelijke staten van de U. S. A. de spin in menige omstandigheid als orakel werd gebruikt, dan komt dit zoowel met de Afrikaansche toestanden overeen, als met het Surinaamsche verhaal (no. 24) waarin Anansi als waarzegger optreedt om zich een lekker hapje te verschaffen. Trouwens, hij bezit de alwetendheid tegelijk met vele andere goddelijke eigenschappen waarop wij nog terugkomen.

De vruchtbare kracht welke men aan de zon toekende, is ook overgegaan op de spin als toonbeeld van sexueele potentie. Bij de Tim bestaat daar menig verhaaltje over (t. a. p.), en ook in West-Indië heeft Anansi de reputatie van een echte schuinsmarcheerder.

Om hem echter in zijn andere eigenschappen nader te leeren kennen, moeten wij terugkeeren tot zijn oorspronkelijke, meest-opvallende bezigheid: die van dradenspinner. Heel veel uiteenloopende dingen verbindt hij met zijn ragfijne draad.

De zon zelve zit aan een draad, verspreidt draden, is in de aanschouwing van sommigen zelfs enkel een dradenkluwen, gelijk bij de Bammana, een Mande-volk, waar verteld wordt dat er twee wevers zijn die de zonnekluwen besturen. Zij rollen een boomwol-draad op en werpen de 
ontstaande kluwen elkander toe. De eene wever heet $\mathrm{Ba}$ dia en woont in het Oosten, de ander heet Tille en woont in het Westen. Tille trekt overdag een kluwen naar zich toe: vanwaar de zonnebaan overdag. Badia trekt onder de aarde door des nachts het kluwen naar zich toe; daarom is de nacht donker.

Maar de boomwoldraad komt sporadisch voor. Bijna altijd is de zonnebaan de draad uit spin's achterlijf; de weg die hij achterlaat, en die hij weer terugloopt.

Met de draad waarlangs de zonnespin zich neerlaat, begint nu zijn aardsche loopbaan; met de draad waaraan hij zich weer ophijscht, begint de mythische „Deutung” van het aardsche diertje. Spin's weg van de aarde naar de hemel, door middel van zijn rag, speelt een groote rol in de sprookjesschat. Deze wnieke faculteit stelt hem in staat met hemelbewoners om te gaan, en daardoor macht uit te oefenen op de aarde.

Een groot aantal sprookjes waarin de spin de middelaar tusschen aarde- en hemel-bewoners is, kennen de Kassaïden (Atlantis XII). Kadifukke („Hij die zich zelf maakt”) is in één sprookje in bondgenootschap met Kapullukussu (de kleine vleermuis), die met een ijzersterke draad voor Kadifukke de gesternten vangt; in een ander sprookje is Tande, de spin, zijn bondgenoot, en blijkbaar is de kleine vleermuis slechts een corruptie van de vliegende spin, die in een derde sprookje voor zijn mede-dieren een brug spint naar een nieuw land.

Het duidelijkst echter is het sprookje waarin het volgende verhaald wordt: „Alle dieren kozen Tande (de spin) en Pepelle (de wind) tot opperhoofden. De dieren zeiden: jullie moet ons de weg naar de hemel wijzen. Pepelle wierp Tande ten hemel. Tande liet zich langzaam aan zijn draad naar beneden. Tande ging langzaam aan zijn draad weer omhoog en spon een andere draad. Tande ging gedurende vijf maanden zijn straat op en neer, op en neer, totdat de weg voltooid was. Tande zei tot de dieren: de weg naar 
Fidi Mukullu (God) is gereed. Alle dieren gingen naar de hemel. Etc.

Overduidelijk heeft de spin hier een dubbele functie: die van periodisch stijgend en dalend zonnedier, en die van verlossers-symbool, van middelaar tusschen God en de schepselen.

In een ander Kassaïden sprookje, als Njadi, het onweersdier, met veel misbaar uit de hemel daalt en Idu, de schildpad, (zonnebeeld) het hem na moet doen, roept hij de hulp in van Dihoka, de spin. Deze maakt dan een sterke weg, en draagt Idu terug naar de aarde. Hij is hier dus rivaal van de Donder, evenals in het Surinaamsche verhaal (Van Cappelle no. 22) van Anansi en de Bliksem, een nog duidelijke zonnemythe die aldus begint: ,,Spin en Bliksem, waren goede vrienden; zij bezochten elkaar dikwijls"'.

Van intermediair brengt de Spin het gemakkelijk tot levensredder en geluksbrenger. Bij de Kassaïden maakt hij voor Tschula, de pad, een weg naar Nsaschi, „ein groszes Tier wie ein Hund, das am Himmel lebt". En zelf neemt hij de pad op zijn rug, daar hij nog steeds als zonnedier zelf de weg aflegt. Een bewijs hiervoor is wel, dat Tande eerst 's nachts naar de aarde terugkeert, overeenkomstig het Surinaamsche sprookje van Anansi en de Bliksem, waarin de twee vrienden elkander steeds te middernacht bezoeken.

Als gelijke gaat hij om met de Hemel en de Dood in een Agni-verhaal dat Cendrars in de "Anthologie nègre" opnam, en met de Dood gaat hij ook om in het Surinaamsche sprookje van Van Cappelle, (no. 15). Deze deelt ook nog een Curaçaosche „Cuenta di Nansi” mede, waarin de spin op raad van zijn vrouw naar God wandelt om verlossing van zijn plagen te erlangen.

Ook bij de Bassari gaat hij opweg naar God om er een kalebas vol wijsheid te halen (Atlantis X). Eerst als hij de kalebas weggooit, wordt wijsheid gemeengoed. Van zijn goddelijke afkomst getuigt de spin zelf, wanneer hij in een Dagomba-sprookje uit midden Togo, op een vraag van de vertoornde hyena antwoordt: „Ik een kind Gods heb het vuur aangestoken!"' 
Zelfs wanneer hij niet meer met God en Hemel in verband gebracht wordt, blijft hij nog de goede gezel die gaarne bereid is weldaden te bewijzen. In een Kassaïdenverhaal is hij de levensredder van zijn Antilopenvriend, doordat hij webben over al diens voetsporen maakt, en de jagers zoo het spoor bijster worden.

Cendrars nam in zijn verzameling een verhaal van de Fân op, waarin Ndanabo de spin het leven redt van het hemelkind Bingo, door een web te maken over de grot waarin hij verscholen is. Ook in een Haoussa-verhaal (Cendrars) is hij de goede gezel van een jonge avonturier van 't Walewein-type. Hij doorziet tooverheksen en tooverkunsten en redt meermalen het leven van de jongeling.

Dit vermogen heeft hij nog over van zijn goddelijke afkomst. Hij is een goed waarzegger, die zooals in het Surinaamsche verhaaltje (v. Cappelle no. 24) zijn kunst simuleert, maar die een andermaal alwetend blijkt, zooals in het sprookje van Anansi en de Bliksem, en als con goddolijk individu zelfs onsterfelijk is, (vgl. v. Cappelle pag. 243), al wordt hij ook menigmaal ter dood gebracht. Hij is een wijs rechter met bijna Goddelijk gezag, gelijk in het verhaal van Hert en Kikvorsch (v. Cappelle no. 20); een geleerde en een geestelijke is hij, al is het gedwongen door honger en roofzucht, (v. Cappelle no. 10); en tenslotte is hij ook een edel heer, een Adonis door alle meisjes geliefd (v. Cappelle no. 2), een gezaghebbend, waardig man, „Granman" Anansi! (zie v. Cappelle no. 1, 2, 3, 6). Iemand die overigens zoowel zijn gezag als zijn groote wijsheid en slimheid op den duur meer ten kwade dan ten goede gaat aanwenden.

Maar voordat de Spin zoo aan lager wal geraakt is, heeft hij nog uit hoofde van zijn heiligbrengende kwaliteiten een eigenaardige rol te vervullen gehad, die hij op sommige plaatsen nog altijd speelt. Namelijk door met zijn lijfelijke aanwezigheid te gelden als een goed voorteeken. Meinhof in zijn „Dichtung der Afrikaner" wijst erop dat de spin als goed voorteeken geldt bij de Togo-stammen, terwijl dit dier volgens zijn "Afrikanische Religionen” ook bij de waarzeggerij een groote rol speelt. En het behoeft geen 
toelichting dat in zulk geval zijn beteekenis zoowel gunstig als onheilbrengend kan zijn.

In een verhaal bij Cendrars vinden wij dan ook als slot van het relaas over een spin die in de functie van yamsbrenger om zijn eigenwijsheid door de booze geesten gedood wordt, de opmerking: „De bewoners van de stad waren in den beginnen blij toen de spin terugkwam; maar nadat zij z'n avontuur gehoord hadden, joegen zij hem boos weg". Ook wordt de spin met de clairvoyance in verband gebracht bij de Mande, waar in een verhaal (Atlantis VII) een Djinn tegen een jager, voordat hij hem meeneemt naar het land van de Djinn, zegt: neem eerst een Dallivrouw (het wijfje van de Dalli-spin), en leg die op je linker oog. Want dat hebben alle Djinn zoo. Later blijkt dat de jager een spinneweb over zijn oog heeft.

Als goed of kwaad voorteeken heeft de spin in WestIndië, voor zoover mij bekend is, niet veel beteekenis. In Noord-Amerika daarentegen wel. „Volgens Puckett: „Folk beliefs of de Southern Negroes”.) Daar wordt ook zijn aanwezigheid in een flesch beschouwd als de vangst van een tooverheks. Typisch voorbeeld van degradatie, wanneer wij weten dat in het Surinaamsch volksgeloof de zon juist beschouwd wordt als doodelijk voor de $A z \dot{e}-$ $m a$ (v. Cappelle pag. 253). Als verdrijver van heksen is de spin zelf ook bekend, o. m. blijkens een sprookje uit Centraal-Soedan (Atlantis IX) waarin hij eerst in gezelschap van een schildpad (de maan?), later alleen ,een gevaarlijke heks weet te verschalken.

Op meer maatschappelijke wijze gaat hij in de Surinaamsche tori met waternimfen en mama om (v. Capp. no. 7. no. 19).

Ook wordt de spin overal beschouwd als een ziekteoorzaak, en is dit een der duidelijkste symbolen geworden van zijn pejoratieve „Deutung”. Niet alleen in de Vereenigde Staten is dat zoo, maar ook in West-Indië, waar de Boschnegers een verhaal hebben (v. Cappelle pag. 348), waarin de Spin, door de anus van den Gouverneur met een geldstuk te verstoppen, diens ziekte teweeg brengt. Dit beletten van de vorstelijke stoelgang is overigens een 
wandaad die de Spin ook in een sprookje uit Noord-Togo (Atlantis XI) begaat. De Noord-Amerikaansche negers nemen nog aan, dat bij sommige maag- en darmstoornissen, een spin zich in het lichaam bevindt, een voorstelling, die volkomen analoog is met de Surinaamsche, welke tot uiting komt in de uitdrukking mi futu tiis' anãsi „mijn voet heeft de spin" voor „mijn been slaapt”.

Hierbij zij terloops opgemerkt dat Schuchardt deze uitdrukking verklaart als subject-object verwisseling, daar het Tsji zegt „ananse akyere me nañ" = de spin heeft mijn voet te pakken. (Die Sprache der Saramakkaneger, pag. 46). De Surinaamsche neger gaat evenwel van de aanschouwing uit, dat een spin in het slapende lichaamsdeel aanwezig is.

Overeenkomstig de Afrikaansche zienswijze zegt de Surinaamsche neger echter: Anãsi kori ju, „de spin heeft je bedrogen" voor ,je hebt gebedwaterd".

In sterkere mate nog, dan de neger de langzamerhand geperverteerde daden van de spin bij zichzelve ging waarnemen, heeft hij deze kosmisch geprojecteerd in de bonte verzinsels van zijn steeds actieve fantasie. Ook dat hangt samen met de goddelijke afkomst van Anansi. Hij kwam voort uit de mythe, en terecht merkte Otto Rank in zijn „Psychoanalytische Beiträge zur Mythenforschung” op, dat de mythe uiteraard ,amoreel” is. Goddelijke helden staan boven elke wet, en Anansi's moed en geslepenheid uiten zich evengoed in het slechte als in het goede. Hij krijgt de ambivalentie van elke Godheid, wordt als een echte Hermes verleener van welstand en dieven-beschermer tegelijk.

En naarmate hij door de rationalistische ontwikkeling van zijn menschelijke onderdanen, door de mythe-vervlakkende werking der „beschaving” zijn solair-gelukbrengend karakter verliest, treden zijn aardsche, biologische en boosaardige kenmerken naar voren.

$\mathrm{Nu}$ hij geen God meer is, en er toch iets van zijn god- 
delijke herinnering overbleef, wordt hij een demon, een demon die op den duur weer heel gemakkelijk verburgerlijkt tot een doodgewone schurk, of de slimmerd uit recht of averecht moraliseerende dierfabels. Als booze demon loopt hij nog rond in een paar Surinaamsche sprookjes; in die waarin hij de buurman van Didibri (duivel) is, en aan deze zijn vrouw verkoopt, maar beide demonen het moeten afleggen tegen een heel sterke toovenaar (v. Cappelle no. 2); en in het verhaal waarin hij uit pure boosaardigheid alle dieren ophitst, en oorzaak wordt van de vijandschap tusschen kippen en kakkerlakken. (v. Cappelle no. 14). Het duivelsche ruziestoken gaat hem goed af, en ook tusschen tijger en konijn weet hij tweedracht te zaaien. (v Cappelle no. 21).

In de Afrikaansche sprookjes laat zijn virtuositeit in het kwaaddoen niets te wenschen over. Een verhaaltje van de Veï (bij Cendrars) leert ons hoe hij door een list aan eten komt. Het is een zeer belangrijk verhaal, daar het vele elementen uit Spin's betere existentie bevat. Er is hongersnood: en het is na het bovenstaande zeker niet gewaagd te zeggen dat zijn frequent optreden bij hongersnooden, die in Afrika het gevolg zijn van ongelukkige droogteprocessen, een oude „,solaire” eigenschap is. In het Veï-verhaaltje is er voorts een vrouw die veel rijst bezit, maar geen kinderen. De spin belooft haar een middel om vruchtbaarheid te verwekken. Zijn bedriegelijke voorspiegeling gaat voor ons echter terug op een tweede oude „solaire” eigenschap, die van vruchtbaarheid-verwekker.

Om zijn belofte gestand te doen, laat hij zich zelf ongemerkt opdrinken door de vrouw. Het kind dat deze baart is de spin. Dit is het derde element, het incarnatieof vermenschelijkings-element. De verbinding tusschen de mythische en de "reëele" wereld geschiedt hier middels de zwangere vrouw, zooals elders middels de spinnedraad.

Het spreekt vanzelf dat in de Afrikaansche sprookjes doorgaans de oude, oorspronkelijke elementen van de spinne-natuur beter bewaard zijn gebleven dan in de verhalen van thans gecreoliseerde volksgroepen. 
Het element van spin's kruipen in een lichaam werd reeds besproken; het komt ook in het volksgeloof der Noord- en Zuid-Amerikaansche negers voor, en is zelfs te vinden in een Surinaamsche tori, waar hij met de tijger in een koe binnendringt, (v. Cappelle no. 4). Zijn functie als vruchtbaarheids-brenger heeft hij nog bij de Tim, waar men een spin aan de hals van kindertjes hangt die niet dik willen worden, en waar men toch ook zijn demonische beteekenis kent, welke tot uiting komt in het gebruik, om wanneer een pasgeboren kind ziek wordt, alle spinnen in huis te vangen en in het water te verdrinken waarmee men daarna het kind wascht.

In Centraal-Soendaneesche spin-verhalen heeft hij een aversie voor landbouw, en staat hij dus negatief tegenover de vruchtbaarheid. En daar hij toch moet eten, wordt hij een schurk .Om slim te worden gaat hij niet meer naar 't Opperwezen, maar naar een van diens menschelijke dienaren; hij is zoozeer aardbewoner geworden, dat hij geen hoogere bijstand meer gebruiken kan.

Zoo is de almacht van Spin verschrompeld tot een meer laag-bij-de-grondsche geslepenheid. De schurkachtige gramã (gouverneur), is elders maar een volkstype, een landbouwer, een paria.

Veel van deze sprookjes, en speciaal die uit centraalSoedan (Atlantis IX) zijn kennelijk corrupt, en zouden doorgaans zonder al te groote moeite ontward kunnen worden. In Noord-Togo bezit de Spin een soort van tafeltje-dek-je, als laatste erfstuk uit zijn voormalige wereldbeheersching. En dan moet hij zich zelfs tegen allerlei monsters, - zooals de vliegende calebas - , verweren, waarin wij toch gemakkelijk de schijngestalten van solaire dubbelgangers kunnen herkennen. (Atlantis XI). Zijn ruzies met de kameleon, die ook bij sommige stammen de beteekenis van een astraal dier heeft, zijn ontaardingen van „hoogere” twisten geworden.

Bij de Tim in Centraal-Togo is de Spin nog verder afgezakt op de maatschappelijke ladder. Daar is hij dikwijls een sul en een zwakkeling, wiens listen worden doorzien, of die door zijn grootspraak zichzelf toch ten leste ver- 
raadt. Hij zit de vrouwen erg achterna, maar zelfs tegenover dezen moet hij het meestal afleggen.

Zoo verliest de Spin eindelijk zelfs zijn menschelijk voorkomen, en wordt hij kort en goed beschouwd als dier, met een dierlijk doen en laten. Hiermede zijn wij beland bij de jongste groep der spin-verhalen, de biologische sprookjes, waarin allerlei morphologische en vitalistische eigenschappen door een metaforisch geconstrueerde gebeurtenis „verklaard" worden.

In Afrika, waar de oudste vormen, gelijk gezegd, nog domineeren, is hun aantal niet zoo erg groot; onder de creoolsche verhalen die veel meer jongere adaptaties en varianten behelzen, zijn zij talrijker. In Suriname worden er tori gevonden, welke verhalen waarom Anansi kakkerlakken en vliegen doodt (v. Cappelle no. 11); waarom hij in de naden en beslagruimten woont (no. 13 en 15); waarom zijn lichaam in tweeën geleed is (no. 18); waarom hij een geglazuurden kop heeft (no. 19). En hij is ook meermalen de oorzaak van de biologische eigenaardigheden van andere dieren (no. 20 en pag. 359).

Een Afrikaansch specimen van biologische spinverhalen geeft Meinhof, die een Ewe-sprookje brengt, dat verklaart waarom het diertje onder de steenen leeft; en hierboven vermeldden wij reeds een verhaal dat aangeeft waarom de spin zijn weg bij kleine gedeelten aflegt.

Een enkele opmerking moet nog over de spinne-familie gemaakt worden. In de oudste verhalen komt hij uiteraard slechts geïsoleerd voor; maar zoodra hij een menschelijke rol speelt, wordt hij onmiddellijk geplaatst in het gezelschap van zijn vrouw. De algemeen-erotische en de vruchtbaarheids-functie van de Spin maakt zooiets begrijpelijk. Hij wordt dan ook een gezegend huisvader, die naarmate hij een lagere maatschappelijke rang inneemt, ook meer moeite heeft om zijn kroost aan het eten te houden. Wanneer hij zijn schurkerijen onderneemt, wordt hij dikwijls door zijn vrouw geholpen, vaker nog door zijn kinderen bijgestaan. Aldus zien wij hem als stamvader van echte schurken-sippe, als een echte Hermes met vele dieven en diefjesmaats onder zich. En eerst wanneer hij 
zuiver als dier wordt opgevat, worden de andere spinnen natuurlijk weer uit het oog verloren, omdat hij nu van persoon tot type is gepromoveerd. Wel zijn er Goudkustverhalen (bij Barker en Sinclair) waarin Anansi's oudste zoon Kweku Tsin hem in slimheid telkens de baas is. Wij kunnen die zoon hier als een voortzetter van het Anansitype vóór de algeheele pejorisatie beschouwen; als een geïdealiseerde plaatsvervanger van den ontaarden vader.

Opmerking verdient dat „Kwaku” de „Woensdag”naam is, en dat ook de vrouw van Anansi in de Surinaamsche vertellingen de Woensdag-naam van $M a A k u b a$ draagt. Juist bij de Noordwestkust-volkeren geldt Woensdag (evenals Zaterdag) als nefast. Deze namen hebben dan ook hoogstwaarschijnlijk betrekking op het demonisch, onheilbrengend karakter der Spinne-familie. In één enkel verhaal bij Barker en Sinclair bezit Anansi zelf óók de voornaam Kweku evenals zijn zoon. Het is duidelijk dat de geheele familie een Woensdagsche, (wij zouden zeggen een „,verdomde”) is. In Suriname golden Woensdags- negers (volgens Teenstra: De Landbouw etc. II) slechts als jaloersch en nieuwsgierig, en niet gelijk de Zaterdagsche als bizonder ongelukkig. De Spin draagt nu zijn dagnaam ook niet langer in Suriname.

(Wordt vervolgd). 